\title{
Yaşlılara yönelik evde bakım hizmetleri sırasında gündeme gelen tıp etiği sorunları
}

\section{Ethical problems come into question during the home care services for elderly people}

\author{
Rana Can*, Lema Çapar Abacı, Selim Kadıoğlu \\ Hemşirelik Bölümü (Yrd. Doç. Dr. R. Can), Mustafa Kemal Üniversitesi, Hatay Sağlık \\ Yüksekokulu, TR-31070 Hatay, Tıp Tarihi ve Etik Anabilim Dalı (L. Ç. Abacı, Doç. Dr. S. \\ Kadıŏlu), Çukurova Üniversitesi Tıp Fakültesi, TR-01030 Adana
}

\section{Özet}

Yaşlı kişilerin genel nüfus içindeki oranı günden güne yükseliş göstermekte, hem bu yükselişin hem de söz konusu kişilerin diğer yaş gruplarındakilere göre daha fazla tıbbi desteğe ihtiyaç duymasının sonucu olarak geriatrik ve gerontolojik uygulamaların tıptaki ağırlığı artmaktadır. Öte yandan hem tıbbın bilimsel ve teknik açıdan ilerlemesine hem de sağlık kavramının daha geniş kapsamlı hale gelmesine bağlı olarak sağlık hizmetlerinin niceliksel ve niteliksel olarak çoğalması çerçevesinde, çağdaş tıbbın bir dönem hastane merkezli bir anlayışı benimseyerek ikinci plana itmiş olduğu evde bakım uygulamaları yaygınlık kazanmaya başlamış bulunmaktadır. Bu iki gelişmenin bir araya gelişi, yaşlılara yönelik evde bakım hizmetlerini daha önemli ve dolayısıyla daha üzerinde durulmaya değer hale getirmektedir. Bu çalışma çerçevesinde, hem evde bakım hem de geriatri-gerontoloji hakkında bir dizi bilgi notu verildikten sonra, genel olarak geriatrigerontoloji etiğine ve yine genel olarak evde bakım etiğine özgü etik sorunların toplu takdimi yapılmış ve bu iki kümenin kesişiminde yer alan sorunlar irdelenmiştir.

Anahtar sözcükler: Evde bakım, tıp etiği, geriatri-gerontoloji

\begin{abstract}
The ratio of elderly people in population is getting higher day by day. As a consequence of this rise and also these people's need for medical support higher than the other age groups, geriatric and gerontological procedures are gaining importance. On the other hand, health services have increased in terms of quality and quantity depending both on the development of the medicine in scientific and technical terms, and the concept of health's being more comprehensive. Because of these increase, home care procedures which were ignored once by the contemporary medicine that supports the hospital-based care have become more widespread. With these two new developments, home care services for elderly people have become more important and so more valuable to focus on. Within the framework of this study, at first some information notes about the home care and geriatric and gerontology are presented, then ethics of geriatrics and gerontology, and ethics of home care are examined in general, and finally ethical issues in the intersection of this two set are evaluated in particular.
\end{abstract}

Keyword: Home care, medical ethics, geriatrics-gerontology

Geliş tarihi/Received: 05 Aralık 2011; Kabul tarihi/Accepted: 07 Kasım 2012

\author{
*İletişim adresi: \\ Dr. Rana Can, Hemşirelik Bölümü, Mustafa Kemal Üniversitesi, Hatay Sağlık Yüksekokulu \\ TR-31070 Hatay. E-posta: ranacan@mku.edu.tr
}

*Bu çalışma 19-21 Ekim 2011'de Şanlıurfa'da gerçekleştirilen 13. Ulusal Hemşirelik Kongresi'nde poster bildiri olarak sunulmuştur. 


\section{Giriş}

\section{Genel olarak ve yaşlılar özelinde evde bakım}

Tıbbın bilimsel ve teknik açıdan ilerlemesine ve sağlık kavramının daha geniş kapsamlı olarak ele alınmasına bağlı olarak sağlık hizmetleri niceliksel ve niteliksel olarak çoğalmaktadır. Bu çerçevede, çağdaş tıbbın yakın geçmişte hastane merkezli bir anlayışı kuvvetle benimseyerek ikinci plana itmiş olduğu evde bakım uygulamaları daha sık gündeme gelmeye başlamıştır [1]. Evde bakım, en genel anlamıyla ihtiyacı olan bireyin alıştığı ortamda tedavisinin ve bakımının sürdürülmesini kapsayan hizmetleri içermekte; kişinin yaşam kalitesini arttırmakta, sosyal izolasyona uğramasını önlemektedir [2, 3]. Sağlık Bakanlığı tarafından hazırlanıp 10 Mart 2005 tarihli ve 25751 sayılı Resmi Gazete'de yayımlanan Evde Bakım Hizmetleri Sunumu Hakkında Yönetmelik'te "evde bakım", "hekimlerin önerileri doğrultusunda hasta kişilere, aileleri ile yaşadıkları ortamda, sağlık ekibi tarafindan tıbbi ihtiyaçlarını karşılayacak şekilde rehabilitasyon, fizyoterapi, psikolojik tedaviyi de kapsayan sağlık, bakım ve takip hizmetlerinin sunulması" şeklinde tanımlanmaktadır [4]. Burada bir parantez açarak yönetmeliğin paternalist bir yaklaşım benimsemiş olma ve var olan tıbbi alt yapı ile uyumlu olmama gibi eleştiriler aldığını not etmek uygun olacaktır [5].

Evde bakım, hem doktor, hemşire, fizyoterapist, psikolog, sosyal çalışmacı gibi sağlık profesyonelleri tarafından verilen tıbbi bakımı hem de hasta yakınlarının tıbbi yönlendirme altında verdiği paramedikal bakımı kapsamaktadır. Büyük bir kısmı tedaviyi sürdürmeye yönelik olan evde bakım uygulamaları, bireylerin gereksinimleri doğrultusunda farklılıklar göstermektedir. Evde bakım, tıbbi tedavinin yanı sıra banyo yapma, kıyafet değiştirme gibi bireysel bakım gereksinimlerinin; evi temizleme, çamaşır yıkama, ortamı yaşamı kolaylaştırıcı duruma getirme gibi evle ilgili gereksinimlerin; mali harcamaları düzenlenme, seyahat etme, sosyal aktivitelere katılma gibi ekonomik ve sosyal gereksinimlerin karşılanmasını da kapsamaktadır [6]. Bu noktada, tıbbın dahliyönlendirmesi olmaksızın, ev ortamındaki gündelik yaşamın bir parçası olarak, gereksinim duyanlara geleneksel yaklaşımlarla verilen bakımın konunun dışında kaldığını; hasta yakınlarının tıbbi direktifler doğrultusunda verdiği paramedikal bakımdan ayrı bir olgu olduğunu vurgulamak yerinde olacaktır. Bu ayrım çerçevesinde, ikinci türde bakım vermesi söz konusu olan ev sakinlerinin sağlık profesyonelleri tarafindan eğitilmesi önem taşımaktadır [7-9].

Günümüz dünyasında, ortalama yaşam süresinin uzamasıyla birlikte hospitalize edilme endikasyonu arz etmemekle birlikte kimi medikal desteklere ihtiyaç duyan yaşlı nüfusun artması; tıptaki ve teknolojideki gelişmelerin sağlik hizmetlerinin birçoğunun evde verilmesine olanak sağlaması; genel olarak hastanede yatış sürelerinin kısalması ve günübirlik cerrahinin artması gibi birçok etken evde bakımın önemini arttırmıştır $[6,7$, 10, 11]. Ülkemizde de evde bakım hizmetlerine yönelik ilgi giderek artmakta; bir yandan bu konuda yukarıda anılan yasal düzenleme hazırlanmış bulunmakta, diğer yandan hem akademik birimler hem de çeşitli kurumlar bilimsel etkinlikler ve eğitim programları düzenlemekte, uygulamaya yönelik projeler geliştirmektedir [12]. Sağlık Bakanlığı'nın organize ettiği evde bakım düzenlemelerinin yanı sıra özel sektör de bu konudaki faaliyetlerini giderek arttırmaktadır [12].

Evde bakımın gündemde ön plana geçmesi doğal ve kaçınılmaz olarak, onun hastanede bakım ile karşılaştırılmasına; avantajlarının ve dezavantajlarının tartışılmasına yol açmaktadır. Evde bakımın başlıca avantajları; hasta özerkliğinin ve özgürlüğünün üst düzeyde olmasını sağlama, hastanın yaşam kalitesini ve çevreyle olan iletişimi arttırma, hastanın-hasta yakınlarının ve sosyal güvenlik kurumlarının giderlerini düşürme, gereksiz hastaneye yatışları azaltma ve hastane enfeksiyonu gibi hastanelere özgü riskleri elimine etmedir [3, 6, 13, 14]. Evde bakımın çeşitli dezavantajları da bulunmaktadır. Bunların başlıcaları, kişinin eve gönderilmekten ötürü umutlarını ve özsaygısını yitirebilmesi; evin sekonder enfeksiyon, yorgunluk, perhize uymama, yanlış yönlendirilme gibi sorunlara açık bir ortam olması; tıbbi otoritenin ev için detaylı bir planlama yapmakta ve yakın bir 
kontrol mekanizması kurmakta güçlük çekmesi; hastanın yanı sıra ev halkının da özel yaşam gizliliğinin zedelenebilmesi; evde yapılan tıbbi uygulamalar sırasında ilaçlarıncihazların hatalı-dikkatsiz kullanımına bağlı komplikasyon gelişme olasılığının artmasıdır $[3,13]$. Kuşkusuz, bu sorunların gündeme gelmesi, evde bakımın belli bir yaygınlıkta verilmesi halinde söz konusu olup, daha erken aşamada yaşanan sorun ise bu hizmetin yeterince verilememesidir [15].

Evde bakım hizmetlerinden, bebeklerden yaşlılara kadar her yaş grubundan kişilerin; özellikle kronik hastalığı olanların, uzun süreli bakıma ihtiyaç duyanların, ileri yaştakilerin faydalanması söz konusudur [13, 14]. Evde bakım, hem kısa süreli hem de uzun süreli bakımın söz konusu olduğu durumlarda, hastane ortamında verilen bakıma alternatif olabilmektedir. Bireyin en kısa sürede kendi kendine yetebilecek duruma gelmesini sağlamaya yönelik olan kısa süreli evde bakım hizmetlerinin başlıcaları, ameliyat sonrası bakım, yara bakımı, hastanın ve ona bakım verenin eğitimi, parenteral ilaç tedavisi ve ağız dışı yollardan besleme uygulamalarıdır. Uzun süreli evde bakım hizmetleri ise, kronik hastalığı olanlar, yaşlılar ve engelliler gibi bakım gereksinimi sürekli olan gruplar için söz konusudur. Bu kategori, sağlı̆̆ korumaya, bakıma muhtaçlık derecesinin artmasını önlemeye, ortadan kaldırılamayan hasta veya engelli olma haliyle birlikte olabildiğince bağımsız yaşamayı sağlayacak becerileri kazandırmaya yönelik uygulamalar içermektedir [13].

Yaşlı kişilerin genel nüfus içindeki oranının artması, sağlık alanında onlara yönelik tedavi, koruma ve rehabilitasyon hizmetlerinin yeniden planlanmasını gündeme getirmektedir [16]. Bu çerçevede yaşlı kişilerin diğer yaş gruplarındakilere göre daha fazla tıbbi desteğe ihtiyaç duymasının sonucu olarak geriatrik ve gerontolojik uygulamaların tıptaki ağırlığı giderek artmaktadır. Yaşlının hem hastalığını teşhis ve tedavi etmeyi hem de sağlığını korumayı ve geliştirmeyi hedefleyen sağlık hizmetlerinin büyük bölümü hastane ortamında gerçekleştirilmekte, ancak bunların bir kısmının evde uygulanmaya uyarlanması da giderek yaygınlık kazanmaktadır. Yaşlılara yönelik evde bakım hizmetleri, onların kendi evlerinde ve çevrelerinde bağımsız olarak yaşayabilmelerini sağlamayı, böylelikle yaşam kalitelerini arttırmayı amaçlamaktadır [3].

Evde bakımlarına yönelik hizmetlerin planlanmasında, yaşlıların sağlığının ve rahatının en üst düzeyde sürdürülmesini ve bozulduğu durumlarda düzeltilmesini sağlamak esastır [6]. Bu yaklaşımın başarısında en önemli unsur koruyucu, tedavi edici, rehabilite edici sağlık hizmetlerinin ve sosyal destek hizmetlerinin entegre edilmesidir [6]. Böyle bir entegrasyon çerçevesinde yaşlının sağlık durumuna ve bakım gereksinimine göre hekim, hemşire, sosyal çalışmacı, psikolog, fizyoterapist, ev ekonomisti, diyetisyen gibi farklı meslek mensuplarının birlikte görev yaptığı ekip çalışması önem kazanmaktadır $[3,14$, $17,18]$.

\section{Yaşlının evde bakımı ve tıp etiği}

Tıp etiği çerçevesinde, monoblok-homojen bir yapının değil, farklı sağlık mesleklerinin, tıp dallarının, uygulama süreçlerinin, hizmet birimlerinin kendilerine özgü etiklerinin kompoze olduğu mozaik bir yapının mevcudiyeti söz konusudur [16]. Bu saptamadan hareketle, hem evde bakım etiğinden ve geriatri-gerontoloji etiğinden hem de daha özel olarak bunların kesişimi olan yaşlı hastaya yönelik evde bakım etiğinden söz etmek olanaklıdır. Anılan bu tıp etiği kategorilerinin ilkinde tıbbi sürecin gerçekleştiği ortam, ikincisinde ise tıbbi ilişkide taraf olan hasta grubu, gerçekleştirilebilecek tıbbi uygulamaları, dolayısıyla olası etik sorunları belirlemekte ve sınırlamaktadır. Üçüncü kategori olan yaşı hastalara yönelik evde bakım hizmetleri bağlamında ise bu sınırlayıcı faktörlerin ikisi birden devreye girmekte; söz konusu edilebilecek etik sorun kategorileri azalmaktadır. Kuşkusuz bu niteliksel azalma, niceliksel bir azalmayı beraberinde getirmemektedir.

Yaşlılara yönelik evde bakım hizmetleri sırasında gündeme gelen tıp etiği sorunlarının kimilerinde tıbbi sürecin evde gerçekleşiyor olması, kimilerinde ise hastanın yaşlı bir kişi 
olması ön plana geçmekte; daha belirleyici hale gelmektedir. Bu sorunları ve onları önlemeye-çözmeye yönelik yaklaşımları ayrıntılı olarak ele almadan önce, genel olarak geriatri-gerontoloji etiği ve genel olarak evde bakım etiği bağlamlarında ortaya çıkması olası tıp etiği sorunlarını kısaca gözden geçirmek uygun olacaktır. Geriatri-gerontoloji etiği sorunları Tablo 1'de, evde bakım etiği sorunları ise Tablo 2'de ana başlıklar halinde yer almaktadir.

İki tablo çaprazlanarak değerlendirildiğinde, yaşlı hastaya evde bakım vermekle ilgilibağlantılı etik sorunlar, biri tabloların birleşim kümesi elemanlarından oluşan daha uzun, diğeri kesişim kümesi elemanlarından oluşan daha kısa iki liste halinde ortaya çıkmaktadır. Söz konusu listelerden kısa olanında yer alan, bir başka söyleyişle hem hastanın yaşlı olmasıyla hem de bakımın evde verilmesiyle ilgili-bağlantılı bulunan sorunlar aşağıda, tematik bölümler halinde, kısa çözümleyici değinmelerle gözden geçirilmiştir.

Tablo 1. Geriatri-gerontoloji etiği sorunları [19].

Yatakta vücut bakımı-temizliği yapılması, boşaltım ihtiyacının giderilmesi, sonda uygulanması gibi işlemler sırasında yaşlı hastaların mahremiyetine özen gösterilmemesi.

Anlama ve karar alma yeteneklerini tam olarak değerlendirmeye gerek görmeden, yaşlı hastalar hakkındaki tıbbi kararların kendileriyle değil yakınlarıyla görüşülerek alınması.

Yaşlı hastaların kronik, hafif ve belirsiz yakınmalarının "yaşa bağlanarak" dikkate alınmaması; ayrıntılı inceleme ve radikal tedavi konusu kabul edilmemesi.

Tolere edemeyecekleri varsayılarak yaşlı hastalara kötü prognozlarının bildirilmemesi.

Yaşlı hastalarla iletişim kurarken, bireysel özelliklerini dikkate almayan, standart bir "yaşlı hasta yaklaşımı"nın benimsenmesi.

Karar verme yeteneğinin tam olmadığı varsayılarak, yaşlı hastanın tedaviyi reddetme hakkının dikkate alınmaması.

Karar verme yeteneklerinin tam olmaması olasılığı göz ardı edilerek, yaşı hastaların tedaviyi reddetme isteklerinin hemen kabul edilmesi.

Geleneksel değerlere bağlılık veya toplumun giderek yaşlanmasını göz önüne alma nedeniyle yaşlı nüfusa daha fazla kaynak ayrılması; bu çerçevede yaşlı hastalara verilen sağlık hizmetlerinin sosyal güvenlik sistemine ağır bir yük getirmesi.

Yakınlarının isteklerinin veya yönlendirmelerinin, kendilerini devre dışı bırakmak pahasına yaşlı hastalara yönelik tıbbi uygulamaların öncelikli belirleyicisi haline getirilmesi.

Anlamayacakları varsayılarak yaşı hastalara durumları hakkında tam ve ayrıntılı bilgi verilmemesi.

Yaşam süresini uzatmayıp sadece yaşam kalitesini arttıracak bakım ve destek uygulamalarının yaşlı hastalardan esirgenmesi.

Terminal dönemdeki yaşlı hastalara agresif tedavi uygulamaları yapılarak, yaşam kalitesini düşürmek pahasına yaşam süresinin uzatılması.

Aydınlatma ve onam almayla başlayan tedavi-bakım sürecinin ilerleyen aşamalarında, yaşlı hastalara bilgi verilmemesi ve onların kararlara ortak edilmemesi.

Terminal dönemdeki yaşlı hastalar hakkında resüsite etmeme kararının, aynı durumdaki genç hastalar hakkında olana göre, daha kolay alınması.

Zihinsel yeterlilikleri olmadığı için tıbbi karar verme sürecine katılamayan yaşlı hastalara, yapılacak işlemler hakkında bilgi verilmemesi.

Yaşlı hastaların muayenesi sırasında ihmal-istismar belirtileri bakımından özel bir değerlendirme yapilmamasi.

Tolere edemeyeceği varsayılarak yaşı hastalara radikal tedavi işlemleri yapmaktan kaçınılması, palyatif desteklerle yetinme eğilimi gösterilmesi.

Yaşlı hastalara, fizyolojik dengelerinin labil oluşu göz ardı edilerek, ileri yaşa özgü olmayan tedavi prosedürlerinin araştırıldığ çalışmalarda denek olarak yer verilmesi.

Toplum geneline hizmet verilen sağlık birimlerinde, yatak, ameliyathane, ventilatör gibi sınırlı tıbbi olanakların sunumunda genç hastalar lehinde yaş ayrımcılığı yapılması.

Yaşlı hastaların yaşam kalitesini arttırma, yaşam süresini uzatma isteklerinin yersiz-yakışıksız bulunmas1, dikkate alınmamas1. 
Tablo 2. evde bakım etiği sorunları [1, 7, 20-23].

Hasta yakınlarının özerkliğine hastanın özerkliğine gösterilenden daha fazla saygı gösterilmesi; tıbbi süreçlerin onların istekleri doğrultusunda yürütülmesi.

Bakımın medikal olmaktan çok medikososyal bir ortamda verilmesinden ötürü hastaya ve yakınlarına yönelik bilgilendirmenin yeterli olamaması.

Kendisiyle kurulan ilişkinin yoğun ve kesintisiz olmaması veya karar verme yeterliliğiyle ilgili kuşkular bulunması nedeniyle hastanın karar süreçlerinin dışında bırakılması, isteklerinin dikkate alınmaması.

Hastanın sır olarak korunmasını istediği bilgilerin yakın mesafede bulunan ve kimi zaman kendileriyle işbirliğine gidilen hasta yakınlarından saklanamaması.

Ortamın uygun olmamasından veya hane halkı arasında çekinme olmayacağının varsayılmasından ötürü hastanın beden mahremiyetinin yeterince korunamaması.

Ortamın uygun olmamasından veya hane halkı arasında çekinme olmayacağının varsayılmasından ötürü hastanın kişisel bilgi mahremiyetinin yeterince korunamaması.

Hastanın sağlık durumunda gerçekleşen olumsuz gelişmelerin erken aşamada fark edilememesi. Hastanın hastaneye özgü acil ve ileri müdahale olanaklarından yararlanamaması.

Terminal dönemdeki hastanın tedaviyi reddetme, resüsitasyon yapılmaması talimatı verme gibi kritik kararlarını ailesinin kabul etmemesi.

Hastanede izlenme endikasyonu olan hastanın veya yakınlarının sosyal izolasyondan çekinme nedeniyle evde bakım almak konusunda israr etmesi.

Hastanede izlenme endikasyonu olan hastanın veya yakınlarının yatış giderlerini karşılayamama endișesiyle evde bakım almak konusunda 1srar etmesi.

Evde bakım sırasında hastaneye sevk endikasyonu doğan hastanın sağlığını-yaşamını riske ederek evde kalmak istemesi.

Hastanın kendisine bakım verenlere duyduğu minnetten ötürü kendisiyle ilgili kararları almayı tamamen onlara birakmasi.

\section{Özerklik, özerkliğe saygı, aydınlatma ve onam ile ilgili sorunlar}

Özerklik kavramı kişi bazında ele alındığında, onun öncelikle yapacakları ve ikincil olarak da kendisine yapılacaklar hakkında son kararı verme gücüne sahip olmasını ifade etmektedir. Hastanın özerk olmasını destekleme ve bu özerkliğe saygı gösterme, çağdaş tıp anlayışının kuvvetle benimsediği ve onu geleneksel tıp anlayışından belirgin biçimde ayıran bir değerdir. Tıbbi ilişkiyle ilgili toplumsal beklenti de özerkliğe saygının esas olması gerektiği merkezindedir [21]. Bu değerin tıbbın gündelik yaşamında ortaya çıkışı en sık aydınlatma ve onam alma yaklaşımı çerçevesinde gerçekleşmektedir. $\mathrm{Bu}$ yaklaşımın esası, hastayı kendisi için öngörülen uygulama konusunda açık, ayrıntıl1, anlaşılır biçimde bilgilendirme ve uygulamayı onun onamı-seçimi doğrultusunda gerçekleştirmedir. Kadim hekimlik değerleri-yaklaşımları olan hastanın mahremiyetini koruma ve sırlarını muhafaza etme, günümüzde özerkliğe saygının birer unsuru olarak değerlendirilmektedir. Sağlık profesyonelinin özerk bir mesleki kimliğe sahip olma ve onun saygınlığını koruma çabası da bu temel değere dayanmaktadır. Yaşlı hastanın evde bakımı sırasında gündeme gelen tıp etiği sorunlarının önemli bir kısmı özerklik ve özerkliğe saygı ilkesi ile bağlantılı olarak oluşmaktadır [16, 20, 24, 25].

Hastanın hem yaşının ilerlemiş bulunması hem de bakım aldığı ortamının ev olması, sağlık profesyonellerinin onu değil yakınlarını muhatap alma eğilimini güçlendirmektedir. Hakkındaki tıbbi kararların biçimlendirilmesinde kendisi yerine yakınlarının ön plana geçmesi ise, evde bakım alan yaşlı hastanın özerkliğinin göz ardı edilmesi ve zedelemesi esprisini taşımaktadır. Özerklik ve özerkliğe saygı ile bağlantılı sorunlar, hasta yakınlarının karar verici olarak devreye girişiyle sınırlı kalmamakta, hastanın anlayabilme ve karar verebilme yeterliliklerinin titizlikle değerlendirilmesi ve bunlara uygun biçimde bilgilendirilme ve onam-seçim süreçlerine dahil edilmesi de, sağlık profesyonellerinin tıp etiği çerçevesinde önem vererek üzerinde durması gereken konular olarak ortaya çıkmaktadır. 
Beden ve bilgi mahremiyetlerine yeterince sayg1 gösterilmemesi, hem evde bakım alan hem de yaşı ilerlemiş olan tüm hastaların ortak sorunudur [16]. Bu durumda evde bakım alan yaşlı hasta, bir yandan hane halkının ortak yaşam alanında bulunmanın, diğer yandan ilerleyen yaşı ve zayıfladığı varsayılan zihin yetenekleri nedeniyle kişisel alanına girilebilir kabul edilmenin sıkıntılarını yaşamaktadır. Hastayı izleyen sağlık profesyonellerine bu durumdan çıkan görev, mahremiyete saygı göstermeyi kişisel yaklaşım olarak benimsemenin ötesinde, hasta yakınlarını da bu şekilde davranmaya yönlendirmektir. Hastanın sır olarak nitelediği bir bilginin mevcudiyeti halinde, onu saklama konusunda da benzer bir sorun potansiyeli bulunmaktadır. Sir saklama ve mahremiyeti koruma sorunlarının benzer nitelikler taşıdığını ve bunları gidemeye yönelik yaklaşımların da paralellik gösterdiğini söylemek olanaklıdır.

Sağlık profesyonelinin hastanın özerkliğine saygılı ve onu geliştirme çabası içinde olmanın yanı sıra kendi mesleki özerkliği konusunda da duyarlı olmalıdır. Bu duyarlılık, ülkemiz ve günümüz koşullarında kendi evindeki yaşlı bir kişinin isteklerinin ve yönlendirmelerinin yaratması olası manevi baskı karşısında mesleki doğrulardan uzaklaşmamayı sağlayacaktır. Yaşlı hastaya yönelik evde bakım çerçevesinde çeşitli tıbbi uygulamaların bulunması ve çoğu zaman aynı hasta için bunların birden fazlasının gündeme gelmesi söz konusudur. Bu durumda birden fazla sağlık profesyoneli aynı kişiye hizmet vermekte, birlikte bir ekip oluşturan bu kişilerin birbirleriyle iyi iletişim kurmanın ve yaptıklarını entegre etmenin yanı sıra birbirlerinin mesleki özerkliklerine saygılı olması, her birinin kendi yetki ve sorumluluk sınırları içinde kalması gerekmektedir [10].

\section{Sosyal, ekonomik, politik, hukuki özel durumlar bağlamında karar verme sorunu}

Tibbi uygulamalar bağlamında etik karar verme süreci, sağlık profesyonelinin mesleki eylemini zihninde biçimlendirdiği, aşamada içinde bulunduğu durumu ve önündeki seçenekleri etik değerler ve kurallar yönünden irdeleyerek ne yapması, nasıl davranması gerektiğini belirlemesini ifade etmektedir [26, 27]. Bu zihinsel süreçte bir yandan mantıkl1, tutarlı, genelgeçer olma gibi soyut unsurları diğer yandan eldeki olanaklarla gerçekleştirilebilirlik, içinde bulunulan çevrede kabul ettirilebilirlik gibi somut unsurları göz önüne almak gerekmektedir. Tıbbi uygulamanın içinde konumlandığı sosyal, ekonomik, politik, hukuki çerçeveler doğal ve kaçınılmaz olarak etik karar verme sürecini etkilemekte, değer dengeleri üzerinde belirleyici olmaktadır [26]. Genelde olduğu gibi evde bakım özelinde de geçerli olan bu belirleyicilik, evde bakımın henüz tam anlamıyla oturmuş-yerleşmiş olmaması nedeniyle fazladan önem kazanmakta; evde bakım bağlamındaki etik karar verme süreçleri sosyal, ekonomik, politik, hukuki durumlardan daha kuvvetle etkilenmektedir.

Tıp etiği sorunların odağında sağlık profesyonelinin mesleki eylemi bulunmakta ve tartışmalar bu eylemin gerekçeleri, belirleyicileri, alternatifleri, sonuçları gibi temalar üzerinde ilerlemektedir. Bununla birlikte bu sorunlara daha geniş açıyla bakıldığında her birinin farklı boyutlara sahip olduğu, farklı unsurlar içerdiği görülmektedir. Ekonomik, sosyokültürel, hukuki ve siyasi boyutlar, etik sorunların yapısında özellikle ağırlı̆̆ını hissettirmektedir. Bu genel saptama, yaşlılara yönelik evde bakım süreçleri özelinde de geçerlidir. Bu süreçlerin de hem olağan seyirlerini düzenleyecek hem de aksamalar1bozulmaları halinde düzelmelerini sağlayacak yasal bir çerçeve gerekmektedir.

Yaşlı hastaların kurum bünyesinde sağlık hizmeti almasının, hem pahalıya mal olması hem de onları gündelik hayattan soyutlaması, yakın çevre içerisinde yaşamı sürdürmeyi sağlayan evde bakım hizmetlerinin yaygınlaştırılmasını gerekli kılmaktadır [10, 17, 28]. Hem hasta hem de yakınları açısından önem taşıyan yaşlıya evde bakım düzeninin yaygın şekilde kurulabilmesinin koşulu ise bu işe yeterli kaynak ayrılmasıdır [20, 29]. Evde bakım konusunda nasıl bir ekonomik model oluşturulacağı, bu hizmetlerin finansmanı için ne kadar kaynak ayrılacağ 1 , ayrılan kaynakların kullanımının ne şekilde denetleneceği, hane halkına ne ölçüde maddi destek verileceği gibi ekonomik ve etik açılımları olan konular Batı literatüründe 1980'lerden, Türk literatüründe ise 2000'lerden beri tartışılmaktadır [1, 10, 20-22, 24, 30]. 
Kurumlar ve gruplar tarafından gerçekleştirilen karar verme süreçlerinden söz ederken "politik" sıfatını kullanmak "etik" sıfatını kullanmaya göre daha uygundur. Bununla birlikte somut bir durumda kurumu-grubu yönetme ya da temsil etme konumundaki bireyin karar vermesi söz konusu olduğunda bu uygunluk konusu akıl karıştırıcı hale gelmektedir. Sağlık siyaseti çerçevesinde sağlık sisteminin içinde evde bakımın ağırlıkta ne olacağının ve ona ne kadar fon ayrılacağının belirlenmesi; tıbbi prosedürlerin oluşturulması çerçevesinde evde bakım endikasyonu kriterlerinin seçilmesi hem politik hem etik olma niteliği taşıyan süreçlerdir. Bunları evde bakım etiğinin makro sorunları olarak nitelemek olanaklıdır. Tıbbin gündelik yaşamında evde bakım etiği karar süreçlerinin ortaya çıkışı da iki farklı düzeyde gerçekleşmekte; belli bir hasta hakkında evde bakım endikasyonu konulmasında majör, evde bakım sırasında ortaya çıkan gelişmeler karşısında eylem seçimi yaparken minör karar verme söz konusu olmaktadır.

Evde bakım almanın hastane olanaklarından yoksun kalmaya neden oluşu, yaşlı hastalar söz konusu olduğunda özellikle önem taşımaktadır [24]. Yaşlı hastaların genel sağlık durumlarının bir dizi kritik denge içermesi, onları var olan hastalıkların alevlenmesine ve yeni hastalıklara yakalanmaya yatkın hale getirmektedir. Bu yatkınlık onlara hastanede değil evde bakım verilmesi kararının daha dikkatle alınması; yarar sağlama ve zarar vermeme dengelerinin hassasiyetle kurulması gereğini ortaya çıkarmaktadır. Hastanede ya da evde bakım kararı alınmasıyla ilgili olarak adalet ilkesi çerçevesinde de bir sorun potansiyeli bulunmakta; hastanede bakımın sınırlı olanak niteliğini taşıdığ durumlarda ise yaşlıya yönelik negatif ayrımcılık riski belirmektedir. Bu bağlamda hastane olanaklarından yararlanmada daha genç olanlara öncelik tanıma kaygısı, yaşlı hastaya evde bakım verilmesinin gerekçesi haline gelebilmektedir.

Terminal dönemdeki yaşlı bir hastada, küratif tedaviden vazgeçilip palyatif uygulamaların da evde yapılmasının öngörülmesi bağlamında, ciddi bir etik değerlendirme ve karar verme sürecinin gerçekleştirilmesi gerekmektedir. Böyle bir öngörü, vakanın kendine özgü niteliklerine göre tedavinin reddi, seçici tedavi, resüsite edilmeme direktifi, pasif ötanazi niteliği taşıyabilmektedir. Yaşamın son döneminde tıbbi bakım genel başlığı altında değerlendirilen tüm bu sorunların, titizlikle üzerinde durulması gereken birer etik boyutu bulunmaktadır [24].

\section{Onurun korunması, ihmal-istismar, ayrımcılık ile ilgili sorunlar}

Özerklik gibi onur da tıbbi ilişki sırasında saygınlığının korunması ve zedelenmesinin önlenmesi gereken bir niteliktir [21, 31]. Tibbi uygulamalar, invaziv-agresif olma derecelerinin artışıyla doğru orantılı olarak hastayı hastalığın yol açtıklarından öte doğal dışı hallere ve kısıtlılıklara sürükleyebilmektedir. Böyle doğallıktan uzak ve kısitlı olmak, kültürden kültüre ve kişiden kişiye farklılık gösteren, onur kırıklığı ve özsaygı kaybı hatta aşağılanma yaşantılarına yol açabilmektedir. Uygulamaların sorunlu boyutlarını içeren ayrıntılı bir bilgi aktarımı yapılıp onam alındıktan sonra mahremiyete azami özen gösterilerek gerçekleştirilmesi, hasta onurunun korunması yönünden etkili-uygun bir yaklaşımdır. Evde bakım çerçevesinde yürütülen uygulamaların hastanelerdekilere göre daha az karmaşık olması onur kırıcı olarak algılanmaların bir ölçüde önüne geçmekte ancak evde mahrem alan oluşturmanın güçlüğü ters yönde etki yaratmaktadır.

Yaşlılar ihmale ve istismara uğrama riski yüksek bir gruptur ve sağlik profesyonellerinin bu grupla kurdukları her türlü mesleki ilişkide ihmal ve istismar belirtileri-bulguları yönünden değerlendirme yapması gerekmektedir [16, 19, 31]. Evde bakım uygulamaları hem söz konusu belirtileri-bulguları saptama hem de soruna doğrudan tanıklık etmek bakımından avantaj sağlamaktadır. Evde bakım hizmeti veren sağlık profesyonelleri, hane halkının ihmal veya istismar niteliği taşıyan yaklaşımları, özellikle hastanın gereksinimlerinin karşılanmasını ertelenmesiyle ortaya çıkan ihmal örnekleri, konusunda dikkatli olmanın yanı sıra bizzat kendilerinin ve çalışma arkadaşlarının bu yönden denetimini de ihmal etmemelidir. 
Bir hasta hakkında evde bakım kararı almada öncelikle referans oluşturan etik değerlerin yarar sağlama ve zarar vermeme olduğunu söylemek olanaklıdır. Ancak karara konu olan kişiye odaklanmayıp sürecin bütününü ve toplumsal arka planını görmeyi sağlayan daha geniş açılı bir bakış benimsendiğinde adil olma ve ayrımcılıktan kaçınma temel değerlerinin de devrede olduğu saptanabilmektedir. Sınırlı kaynakların dağıtımında yaşlılara yönelik negatif ayrımcılık tıpta da kimi uzantılarına rastlanan önemli bir toplumsal sorundur [25, 31]. Evde bakım kararının karara konu olanlara yarar sağlamaktan çok hastane olanaklarını başkaları için kullanmak adına alınması, yaş ayrımcılığı veya prognoz ayrımcılığı gibi uygunsuz yaklaşımların göstergesidir.

Sonuç olarak; yaşlılara yönelik evde bakım hizmetleri sırasında gündeme gelen tıp etiği sorunlarını ana hatlarıyla gözden geçirdikten sonra, metni genel bir değerlendirme yaparak tamamlamak uygun olacaktır. Bir yandan yaşlı nüfusun günden güne artması onlara yönelik sağlık hizmetlerinin yeniden planlanmasını gündeme getirmekte, diğer yandan tıbbın yeniden keşfettiği evde bakım hizmetleri hızlı bir gelişim göstererek sağlık alanındaki ağırlığını arttırmaktadır. Bu iki gelişmenin buluşması olan yaşlı hastaya evde bakım verilmesi ülkemiz ölçeğinde yeni yeni yapılandırılmaktadır. Bu yapılandırma sürecinde konunun teknik-medikal ve etik boyutlarının incelikle ve ayrıntılı olarak değerlendirilmesi, uzun ve orta vadede söz konusu hizmetin etkili ve verimli olarak sürdürülmesini sağlayacaktır.

\section{Kaynaklar}

1. Preto N, Mitchell I. Ethical issues in home care: Summary and overview of presentations and discussions at the annual meeting of the canadian bioethics society october 28-31, 2004. Erişim; (http://www.hc-sc.gc.ca/hcssss/alt_formats/hpb-dgps/pdf/pubs/2004-ethi-homedomicile/2004-ethihomedomicile-eng.pdf) (Erişim tarihi: 04.09.2013).

2. Cingil D. Evde bakımda etik, iletişim ve kültürel yaklaşımlar. Erişim; (http://www.google.com.tr/url?sa=t\&rct=j\&q=\&esrc=s\&frm=1\&source=web\&cd $=1 \&$ ved=0CE8QFjAA\&url=http $\% 3 \mathrm{~A} \% 2 \mathrm{~F} \% 2 \mathrm{Fwww} \cdot$ konyasm.gov.tr\%2Fesh $\% 2 \mathrm{~F}$ egitim\%2Fevde_bakimda_etik.pptx\&ei=09L7T56GFKmC4gSWmdzpBg\&usg= AFQjCNGIVExia3_IFKBOmy3oS-9J8A2BLw\&sig2=o7I1lgDoPvu7VUVbMkEdg) (Erişim tarihi: 04.09.2013).

3. Öztop H, Şener A, Güven S. Evde bakımın yaşlı ve aile açısından olumlu ve olumsuz yönleri. Yaşlı sorunları araştırma dergisi, 2008; 1: 39-49.

4. Evde bakım hizmetleri sunumu hakkında yönetmelik. Resmi gazete, tarihi 10.03.2005, say1 25751. Erişim; (http://www.saglik.gov.tr/TR/dosya/131144/h/evde-bakim.doc) (Erişim tarihi: 04.09.2013).

5. İzgi MC, Çoban M, İzgi VA. Evde bakım hizmetleri sunumu hakkında yönetmelik'e eleştirel bakış. T1p etiği, hukuku, tarihi 2008; 16: 43-8.

6. Erdil F. Yaşlanan toplum ve yaşlının evde bakımı. Erişim; (http://www.ekutuphane.teb.org.tr/pdf/tebakademi/geriatri_2009/23.pdf) (Erişim tarihi: 04.09.2013).

7. Talkington S. Ethical issues in home care. HEC Forum 1995; 7: 290-5.

8. Koyuncu Yaşar E. Yaşlıya evde bakım veren aile bireylerinin bakım yükü ve etkileyen faktörler. Danışman Bayık Temel A. Ege Üniversitesi Sağlık Bilimleri Enstitüsü Halk Sağlığı Hemşireliği Anabilim Dalı yüksek lisans Tezi. İzmir, 2009.

9. Dayanır Cingil D. Aile İçi Bakım Vericileri eğitmenin bağımlı yaşlıların evde bakım kalitesine etkisi. Danışman Bodur S. Selçuk Üniversitesi Sağlık Bilimleri Enstitüsü Hemşirelik Anabilim Dalı Yüksek Lisans Tezi. Konya, 2003.

10. Doğan O. Şizofreni hastalarının evde bakımı. Anadolu Psikiyatri Dergisi 2001; 2: 41-6.

11. Erdil F, Bayraktar N. Cerrahi hastasının evde bakımı. Sağlık ve Toplum Dergisi 2004; 14: 3-8. 
12. Akdemir N, Bostanoğlu H, Yurtsever S, Kutlutürkan S, Kapucu S, Canlı Özer Z. Yatağa bağımlı hastaların evde yaşadıkları sağlı sorunlarına yönelik evde bakım hizmet gereksinimleri. Dicle Tip Dergisi 2011; 38: 57-65.

13. Yilmaz M, Sametoğlu F, Akmeşe G, Tak A, Yağbasan B, Gökçay S, Sağlam M, Doğanyılmaz D, Erdem S. Sağlık hizmetinin alternatif bir sunum şekli olarak evde hasta bakımı. İstanbul Tip Dergisi 2010; 11: 125-32.

14. Cindoruk M, Şen İ. Yaşlının evde bakımı. Türkiye Klinikleri Tıp Bilimleri Dergisi 2009; 29: 110-2.

15. Subaşı N, Öztek Z. Türkiye'de karşılanamayan bir gereksinim: Evde bakım hizmeti. TSK Koruyucu Hekimlik Bülteni 2006; 5: 19-31.

16. Can R. Tıp Etiği çerçevesinde geriatri-gerontoloji alanlarında umut yönetimi. Danışman: İ Uzel. Çukurova Üniversitesi Sağlık Bilimleri Enstitüsü Doktora Tezi, Adana, 2011.

17. Bahar A, Parlar S. Yaşlılık ve evde bakım. Fırat Sağlık Hizmetleri Dergisi, 2007; 2: $32-39$.

18. Home-based Long-Term Care. Report of a WHO Study Group. World Health Organization, Geneva 2000: 1-5.

19. Can R, Erenoğlu R, Kadığlu S, Kadığlu F. Geriatri merkezinde çalışan sağlık profesyonellerinin tıp etiği sorunlarıyla ilgili deneyimleri ve görüşleri. Türk Tıp Etiği ve Tıp Hukuku Araştırmaları Yıllığı 2009-2010; 2-3: 177-88.

20. Boillat ME, Gee D, Bellavance F. Ethical conflicts in home care: Patient autonomy and physician advocacy. Canadian Family Physician 1997; 43: 21362142.

21. Doğan H, Değer M. Nursing care of elderly people at home and ethical implications: An experience from İstanbul. Nursing Ethics 2004; 11: 553-67.

22. Garcia T. Ethics in home care. Home Health Care Management \& Practice. 2006; 18: 133-7.

23. Collopy B, Dubler N, Zuckerman C. The ethics of home care: Autonomy and accommodation. Hastings Cent Rep 1990; 20: 1-16.

24. Tanlı S, Utku T. Evde bakımda organizasyon ve etik sorunlar. Türk Yoğun Bakım Derneği Dergisi 2008; 6: 58-63.

25. Childress JF. Ensuring care, respect, and fairness for the elderly. Hastings Cent Rep 1984; 14: 27-31.

26. Kadıŏlu F, Kadıŏlu S. Klinik Uygulamalarda Etik Karar Verme Süreci. Ed Demirhan Erdemir A, Oğuz Y, Elçioğlu Ö, Doğan H. Klinik Etik. İstanbul, Nobel Tip Kitapevleri 2000: 65-84.

27. Yıldırım G, Kadığglu S. Etik ve tıp etiği temel kavramları. CÜ Tıp Fakültesi Dergisi, 2007; 29: 7-12.

28. Aksu T, Fadıloğlu Ç. Yaşl1lıkta evde bakıma güncel yaklaşımlar: "Telefon Zinciri Yöntemi ve Kurtarıcı Servisler Teknolojisi". Maltepe Üniversitesi Hemşirelik Bilim ve Sanatı Dergisi 2010; 2: 119-25.

29. Karahan A, Güven S. Yaşlılıkta evde bakım. Geriatri. 2002; 5: 155-9.

30. Doty P. Family care of the elderly: The role of public policy. Milbank Q 1986; 64: 34-75.

31. Galloway J. Dignity, values, attitudes, and person-centred care. Ed Hindle A, Coates A. Nursing Care of Older People: A Textbook for Students and Nurses. New York, Oxford University Press 2011: 9-22. 